\title{
Biokomposit Hidrogel dengan Ekstrak Centella asiatica sebagai Penutup Luka
}

\author{
Dominique Gian Leonardo ${ }^{1}$, Stephanie Singajaya ${ }^{1}$, Dinda Fluor Agustin ${ }^{1}$, Mariana \\ Wahjudi $^{1 *}$ \\ ${ }^{1}$ Prodi Biologi, Fakultas Teknobiologi, Universitas Surabaya, Surabaya-Indonesia \\ * corresponding author: mariana_wahyudi@staff.ubaya.ac.id
}

\begin{abstract}
When wounds occur on skin, cell regeneration and healing process will occur. Imperfect cell regeneration will end up leaving ugly scars. Any open wounds will have a high chance of being infected, further slowing the healing processes. The bacteria involved in wound infection are as follow: Pseudomonas aeruginosa, Escherichia coli and Staphylococcus aureus. The usage of current medical adhesive to cover wound has many implications: cannot be used multiple times and untuk may end up resulting in MARSI (Medical Adhesive-Related Skin Injuries). This research aims to find an alternative wound dressing that are able to solve the problems mentioned earlier. The synthesis of biocomposite hydrogel consists of bacterial cellulose mixed with gelatin with the crosslinker agent glutaraldehyde. The mixture is then given the wild herbs Centella asiatica extract as an active ingredient. It has been found that the best formulation consists of using 10\% gelatine: bacterial cellulose paste with the ratio 200:1 with the total glutaraldehyde concentration of 1\%. Furthermore, Centella asiatica $10 \%$ are not able to penetrate the human model skin, and did not exhibit any antimicrobial activity against Escherichia coli, Pseudomonas aeruginosa, and Staphylococcus aureus.
\end{abstract}

Keywords: biocomposite hydrogel, nata de coco, bacterial cellulose, gelatine, centella asiatica extract, wound dressing

\begin{abstract}
Abstrak-Ketika luka terjadi pada kulit, regenerasi sel dan proses penyembuhan akan terjadi. Regenerasi sel yang tidak sempurna dapat menghasilkan bekas luka yang kurang enak dipandang. Selain itu, luka terbuka berisiko terinfeksi oleh patogen sehingga penyembuhan akan terhambat. Bakteri yang berperan pada infeksi luka adalah Pseudomonas aeruginosa, Escherichia coli dan Staphylococcus aureus. Penggunaan medical adhesive untuk menutup luka punya banyak kekurangan yaitu penggunaannya tidak bisa dilakukan berulang dan dapat menyebabkan MARSI (Medical Adhesive-Related Skin Injuries), yaitu berbagai komplikasi dan luka pada kulit yang ditempeli dengan produk tersebut. Penelitian ini bertujuan untuk mendapatkan alternatif penutup luka terbaru yang dapat mengatasi permasalahan yang telah disebutkan. Pembuatan hidrogel biokomposit terdiri dari selulosa bakteri yang direaksikan dengan gelatin menggunakan agen crosslinker glutaraldehida. Campuran kemudian ditambahkan bahan aktif dari ekstrak tanaman liar Centella asiatica. Didapatkan formulasi terbaik menggunakan perbandingan $10 \%$ gelatin:pasta selulosa bakteri = 200:1 dengan konsentrasi total glutaraldehida sebanyak 1\%. Selain itu, ekstrak Centella asiatica 10\% juga tidak dapat mempenetrasi model kulit manusia, serta tidak memiliki aktivitas antibakteri baik pada Escherichia coli, Pseudomonas aeruginosa, dan Staphylococcus aureus.
\end{abstract}

Kata kunci: hidrogel biokomposit, nata de coco, selulosa bakteri, gelatin, ekstrak centella asiatica, penutup luka

\section{PENDAHULUAN}

Menurut Bayat (2003) setiap hari di negara maju sebanyak 100 juta pasien terluka, dan 55 juta di antaranya menjalani operasi secara elektif, serta 25 juta di antaranya menjalani operasi setelah adanya trauma. Regenerasi sel yang tidak sempurna dapat menghasilkan bekas luka yang kurang enak dipandang. Selain itu, infeksi luka merupakan komplikasi yang paling mahal setelah operasi (Sen et al., 2009). Faktanya, lebih dari 25 milyar \$US dikeluarkan setiap tahunnya di Amerika Serikat untuk mengobati luka berat. Luka terbuka dapat berisiko terinfeksi oleh patogen sehingga penyembuhan akan terhambat (Ovington, 2003). Bakteri yang biasanya berperan pada infeksi luka adalah Pseudomonas aeruginosa, Escherichia coli (Guo \& DiPietro, 2010) dan Staphylococcus aureus (McCaig et al., 2006). Penggunaan medical adhesive untuk menutup luka punya banyak kekurangan yaitu penggunaannya tidak bisa dilakukan berulang dan dapat menyebabkan MARSI (Medical Adhesive-Related Skin Injuries), yaitu berbagai komplikasi dan luka pada kulit yang ditempeli dengan produk tersebut. Subjek harian dari Fasilitas Kesehatan milik Universitas di daerah Midwestern United States menunjukkan prevalensi MARSI berkisar antara 3,4\% sampai 25\% (Farris et al., 2015).

Centella asiatica atau yang kerap disebut sebagai daun kaki kuda atau pegagan di Indonesia, merupakan tanaman liar yang umum ditemukan di berbagai belahan dunia, di antaranya Asia dan Afrika Tengah (Somchit et al., 2004). Senyawa aktif yang terkandung di 
dalamnya adalah asam triterpen yang mengandung saponin dan gula esternya, yaitu asiatic acid, madecassic acid and asiaticosides yang memberi efek positif pada penyembuhan luka (Brinkhaus et al., 2000) dan merangsang sintesis kolagen (Maramaldi et al., 2013). Walaupun telah terbukti bahwa ekstrak Centella asiatica mempunyai aktivitas antibakteri (Lalitha et al., 2013) namun masih belum ada pengaplikasian ekstrak ini pada hidrogel sebagai penutup luka yang praktis.

Hidrogel biokomposit merupakan gel polimer yang tersusun atas rantai senyawa polimer yang terhubung atas ikatan crosslinking. Hidrogel biokomposit mempunyai biokompabilitas tinggi (Gatenholm \& Klemm, 2010) sehingga tidak menghasilkan reaksi imunogenik (Mendes et al., 2009). Selain itu aman bagi penderita MARSI karena tidak menempel kuat pada kulit, namun memiliki tingkat efisiensi drug delivery yang baik (Treesuppharat et al., 2017). Hidrogel komposit juga merupakan produk yang dapat digunakan berulang dan dapat diproduksi menggunakan bahan yang mudah diperoleh sehingga lebih murah dan ramah lingkungan.

Tujuan penelitian ini adalah menentukan formulasi terbaik hidrogel biokomposit dengan penambahan ekstrak Centella asiatica, mengetahui apakah terjadi difusi ekstrak Centella asiatica dalam hidrogel biokomposit ke membran kulit sintetik, dan mengukur aktivitas antimikroba hidrogel biokomposit yang telah ditambahkan ekstrak Centella asiatica.

\section{Bahan dan Metode Penelitian Bahan Penelitian}

Alat yang digunakan adalah waterbath, peralatan gelas (gelas ukur, gelas arloji, gelas beaker, pengaduk kaca, spreader), mikropipet, ose, pinset, kulkas, bunsen, cawan petri disposable, Centrifuge dan blender (Sharp). Bahan yang diperlukan adalah bubuk Centella asiatica (Herbal Alami Natural), selulosa bakteri yang diekstrak dari nata de coco (Inaco), gelatin (Brataco), glutaraldehida (Sigma), $\mathrm{NaOH}$ (Merck), etanol teknis, ampicillin (Amresco), chloramphenicol (Sigma), spiritus dan akuades. Bakteri yang digunakan adalah Pseudomonas aeruginosa, Escherichia coli, dan Staphylococcus aureus diperoleh dari UBAYA Culture Collection.

\section{METODE}

\section{Pembuatan Hidrogel Biokomposit Selulosa Bakteri (SB) - Gelatin}

Prosedur kerja adalah sebagai berikut (Treesuppharat, et al., 2017): SB yang diekstrak dari nata de coco dibilas dengan akuades untuk menghilangkan kelebihan gula dan ditambahkan $0,1 \mathrm{M} \mathrm{NaOH}$ pada suhu $80^{\circ} \mathrm{C}$ selama 1 jam untuk menghilangkan mikroorganisme, lalu dibilas dengan akuades hingga pHnya netral, kemudian diblender hingga berbentuk pasta. SB dicampur dengan larutan $10 \mathrm{wt} \%$ gelatin dengan rasio $(\mathrm{v} / \mathrm{v})$ perbandingan antara larutan $10 \mathrm{wt} \%$ gelatin dan pasta selulosa bakteri yang digunakan adalah 1:200 karena swelling ratio pada akuadesnya tinggi $( \pm 500 \%)$, memiliki kemampuan menyerap paling tinggi serta mempunyai area permukaan yang spesifik $\left(55 \mathrm{~m}^{2} / \mathrm{g}\right)$. Campuran tersebut kemudian ditambahkan glutaraldehid dengan konsentrasi $1 \%$ dan $0.5 \%$ sebagai agen crosslinking. Campuran semua bahan yang telah disebutkan tersebut dituang ke dalam pencetak dan diletakkan pada oven pada suhu $55{ }^{\circ} \mathrm{C}$ selama 4 jam kemudian dipotong berukuran tertentu $( \pm 0.5 \times 0.5 \mathrm{~cm}$ atau $\pm 1 \times 1 \mathrm{~cm})$.

Untuk Drug-loading dilakukan dengan swelling-diffusion method. Hidrogel berukuran tertentu tersebut direndam dalam larutan ekstrak Centella asiatica 10\%. Sebagai kontrol, gel direndam dalam masing-masing larutan berikut ini: larutan chloramphenicol $5 \mu \mathrm{g} / \mathrm{ml}$, ampicillin $5 \mu \mathrm{g} / \mathrm{ml}$, dan akuades. Inkubasi dilakukan pada suhu $25^{\circ} \mathrm{C}$ selama $24 \mathrm{jam}$.

Formulasi hidrogel biokomposit terbaik ditentukan dengan kualitasnya berdasarkan karakteristik fisik hidrogel yang dilakukan dengan metode sebagai berikut.

- Pengukuran rasio pembengkakan (swelling ratio) hidrogel menggunakan persamaan (Treesuppharat, et al., 2017): 
Swelling ratio $=(\mathrm{W}$ swollen $-\mathrm{W}$ dry $) / \mathrm{W}$ dry $\times 100 \%$, dengan $\mathrm{W}$ swollen $=$ massa ketika membengkak dan $\mathrm{W}$ dry = massa ketika kering. Standard hidrogel dikatakan baik adalah ketika swelling rasio-nya 500\% (Treesuppharat, et al., 2017).

- Pengukuran entrapment efficiency (EE) pada hidrogel menggunakan persamaan (M.C.I.M. Amin, et al., 2012):

$\mathrm{EE}(\%)=[(\mathrm{Wo}-\mathrm{Wf}) / \mathrm{Wo}] \times 100$, dengan $\mathrm{Wo}=$ jumlah total ekstrak sebelum dimasukkan ke dalam hidrogel dan Wf = jumlah total ekstrak setelah dimasukkan ke dalam hidrogel. Standard hidrogel dikatakan baik adalah ketika swelling rationya $45 \%$ (M.C.I.M. Amin, et al., 2012).

- Pengukuran keelastisitasannya (direnggangkan menggunakan tangan).

- Pengukuran difusi senyawa antibakteri yang akan dijelaskan lebih lanjut pada metode 3.4.

\section{Pengujian Kemampuan Difusi Ekstrak Centella Asiatica Pada Biohidrogel Melewati Membran Sistem Kulit Model Manusia}

Berdasarkan teori Somboonwong et al. (2012), luka yang diberi ekstrak air tanaman tersebut mampu meregenerasi jaringan dan menyembuhkan luka bakar lebih cepat daripada yang tidak diberi perlakuan dan metode ekstraksi yang dilakukan Lalitha et al. (2013) yaitu menggunakan akuades, terbukti bahwa ekstrak mampu menginhibisi pertumbuhan dari berbagai bakteri dengan efek cukup setara dengan berbagai antibiotik.

Sebanyak 10 gram bubuk daun Centella asiatica dicampurkan ke dalam $100 \mathrm{ml}$ akuades steril dan diaduk. Campuran kemudian di sentrifugasi pada $4000 \mathrm{rpm}$ selama 5 menit. Supernatan disaring dengan kertas saring Whatman No.1 dan hasilnya disimpan (aseptik) pada botol cokelat steril pada suhu $4{ }^{\circ} \mathrm{C}$. Untuk uji prediksi difusi ekstrak Centella asiatica, biokomposit hidrogel dengan konsentrasi glutaraldehida $1 \%$ dipotong berukuran tertentu dan direndam dalam ekstrak Centella asiatica selama 24 jam pada suhu ruang $\left(25^{\circ} \mathrm{C}\right)$ dan di letakkan di atas potongan kulit telinga babi bagian dorsal. Kulit telinga babi bagian dorsal digunakan sebagai model prediksi difusi ke kulit manusia karena memiliki struktur dan karakteristik biokimia yang mirip dengan kulit manusia, sehingga bagus digunakan untuk studi permeasi senyawa ke kulit (Simon et al., 2016). Untuk mendapatkan kulit telinga babi bagian dorsal, bagian kulit dorsalnya diiris setebal \pm 1 - $2 \mathrm{~mm}$, kemudian dipotong sebesar $\pm 1,5 \times 1,5$ $\mathrm{cm}$. Susunan tersebut diletakkan di atas agar dengan olesan kultur E. coli, P. aeruginosa, dan $S$. aureus. Hasil yang diharapkan adalah ekstrak Centella asiatica mampu menembus kulit telinga babi sehingga hasil akan berupa zona inhibisi disekitar membran sintetik. Semakin besar zona inhibisinya, maka semakin baik karena menunjukkan ekstrak Centella asiatica berhasil dilepaskan dari hidrogel dan memiliki sifat antibakteri.

\section{Pengujian Antibakteri Dengan Menggunakan Biokimposit Hidrogel Pada Staphylococcus Aureus, Pseudomonas Aeruginosa, dan Escherichia Coli}

Uji antibakteri difusi dilakukan dengan meletakkan potongan biokomposit hidrogel dengan konsentrasi glutaraldehida $1 \%$ yang telah direndam: chloramphenicol $5 \mu \mathrm{g} / \mathrm{ml}$, ampicillin $5 \mu \mathrm{g} / \mathrm{ml}$, akuades, ekstrak Centella asiatica 3\% atau 10\% selama 24 jam pada suhu ruang $\left(25^{\circ} \mathrm{C}\right)$ diatas spread plate kultur bakteri E. coli, P. aeruginosa, dan S. aureus. Pengamatan dilakukan dengan melihat hasil dari zona inhibisi dari ekstrak Centella asiatica yang dibandingkan dengan zona inhhibisi dari antibiotik seperti ampicillin dan chloramphenicol.

\section{HASIL DAN BAHASAN}

Telah dilakukan sintesis biokomposit hidrogel dengan variasi menggunakan glutaraldehida $0,5 \%$ dan $1 \%$ dan hasil keduanya mampu menghasilkan biokomposit hidrogel yang elastis. Dari hasil uji elastisitas (Gambar 1), terlihat bahwa biokomposit hidrogel dengan glutaraldehida 0,5\% mampu direnggangkan lebih panjang daripada $1 \%$, namun juga lebih rapuh. Hal ini dapat dijelaskan karena konsentrasi glutaraldehida yang semakin kecil berarti 
agen cross-linker makin sedikit, menyebabkan integritas hidrogel lebih rapuh dan ikatan antar molekul lebih jarang. Terlihat bahwa diameter hambat tumbuh bakteri sedikit lebih besar pada perlakuan glutaraldehida 0,5\% (pada semua perlakuan kecuali akuades/kontrol negatif), disebabkan lebih sedikitnya agen cross-linker menyebabkan struktur hidrogel yang lebih longgar dan berpori lebih besar. Hal ini menyebabkan senyawa lebih mudah masuk hidrogel dan keluar berdifusi pada medium agar. Selain itu, terlihat perlakuan glutaraldehida $0,5 \%$ meleleh sebagian saat diinkubasi bersama medium padat bakteri pada suhu $37{ }^{\circ} \mathrm{C}$. Atas pertimbangan di atas, maka dipilih biokomposit hidrogel konsentrasi glutaraldehida $1 \%$ untuk tahap selanjutnya.

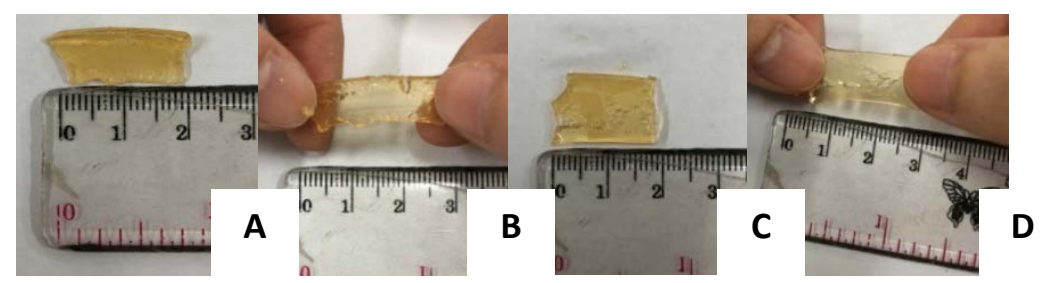

Gambar 1. Uji elastisitas hidrogel biokomposit. keterangan: A dan B menggunakan glutaraldehida $0,5 \%$ sedangkan $C$ dan D menggunakan glutaraldehida $1 \%$.

Dari hasil uji difusi ke model kulit dorsal telinga babi (representatif kulit manusia) pada Gambar 2, tidak terlihat adanya diameter hambat pada semua jenis bakteri. Hal ini berarti ekstrak Centella asiatica pada biokomposit hidrogel tidak sampai menembus kulit dan hanya bekerja pada area yang terluka.

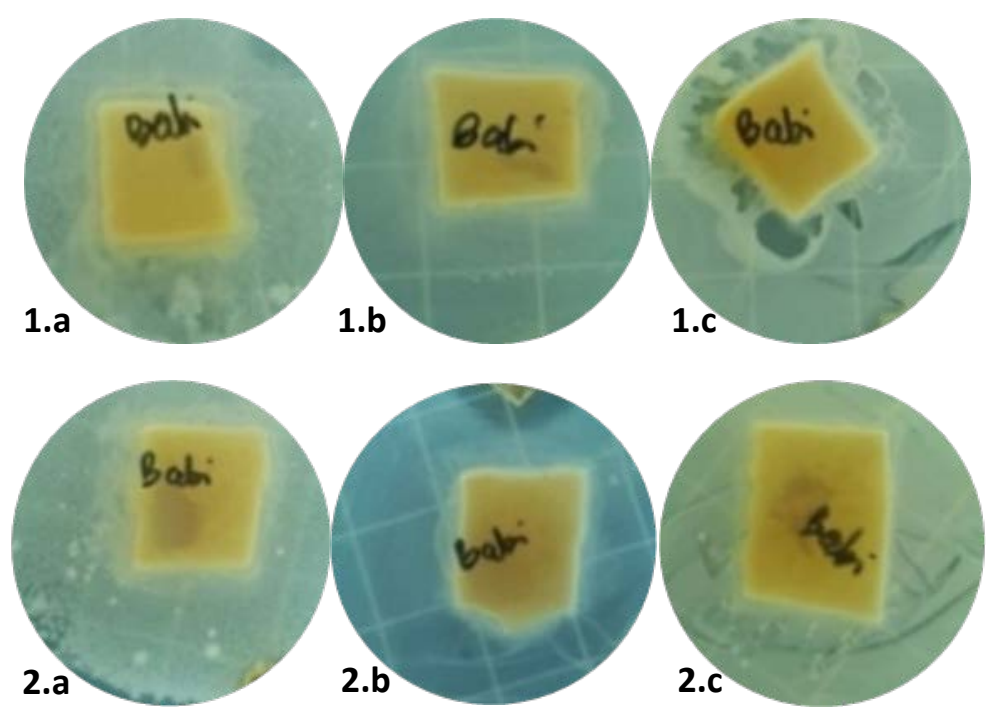

Gambar 2. Uji difusi representatif kulit manusia dengan hidrogel beukuran $\pm 1 \times 1 \mathrm{~cm}$ terhadap sel bakteri. Keterangan: (a) E. coli, (b) P. aeruginosa, dan (c) S. aureus. Gambar 1a-1c menggunakan glutaraldehida $0,5 \%$ dan gambar $2 a-2 c$ menggunakan $1 \%$.

Penelitian selanjutnya dilakukan dengan menggunakan hidrogel biokomposit dengan

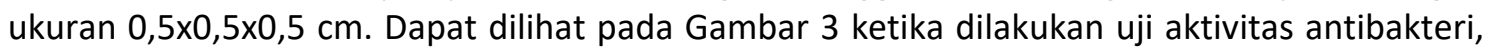
zona inhibisi terbesar pada E. coli terjadi ketika menggunakan ekstrak Centella asiatica sedangkan pada S. aureus terjadi kesamaan zona inhibisi antara ekstrak dan antibiotik. Nilai Swelling Ratio pada hidrogel yang direndam Centella asiatica selama 24 jam adalah 5,89\% dan nilai entrapment efficiency (EE) adakah 7,5\%. 


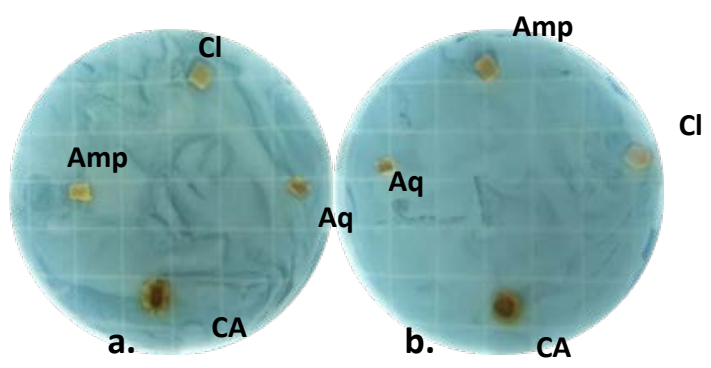

Gambar 3. Uji antibakteri dengan menggunakan glutaraldehida $1 \%$ pada hidrogel dengan ukuran $\pm 0,5 \times 0,5 \mathrm{~cm}$ dengan ketebalan 0,5 cm (a) E. coli, (b) S. aureus. (CA: Centella asiatica, $\mathrm{Cl}$ : Chloramphenicol, Amp: ampicillin, Aq: akuades).

Tabel 1

Zona Inhibisi Penggunaan Hidrogel Biokomposit Ukuran 0,5 × 0,5 cm Dengan Ketebalan 0,5 cm Menggunakan Glutaraldehida 1\%

\begin{tabular}{ccc}
\hline & \multicolumn{2}{c}{ Diameter daerah hambat $(\mathbf{c m})$} \\
\cline { 2 - 3 } & E. coli & S. aureus \\
\hline Centella asiatica 10\% & 0,250 & 0,100 \\
Akuades & 0,000 & 0,000 \\
Ampicillin & 0,100 & 0,100 \\
Chloramphenicol & 0,200 & 0,100 \\
\hline
\end{tabular}

Sebagai perbandingan, dilakukan hidrogel biokomposit berukuran $1 \times 1 \mathrm{~cm}$ dengan ketebalan 0,5 cm. Nilai Swelling Ratio dan entrapment efficiency pada hidrogel yang direndam Centella asiatica selama 24 jam adalah 41,42\% dan 8,11\%, sedangkan yang direndam 48 jam adalah $44.42 \%$ dan $17.5 \%$. 


\section{Replikasi}

1

(a) E.coli

(b) S. aureus

(c) P. aeruginosa

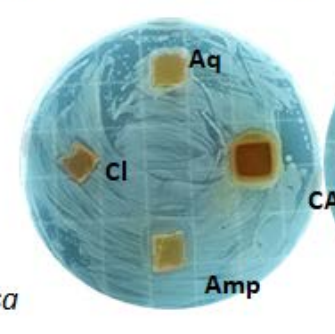

II

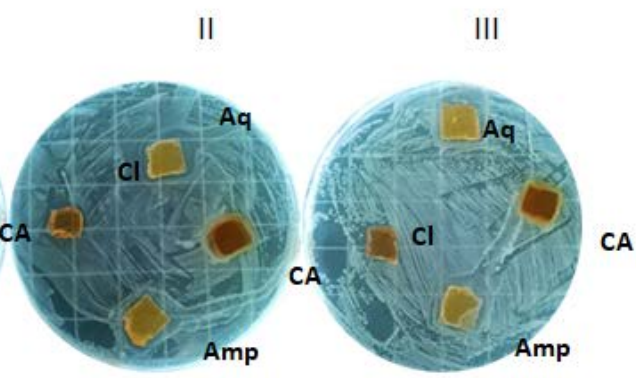

CA

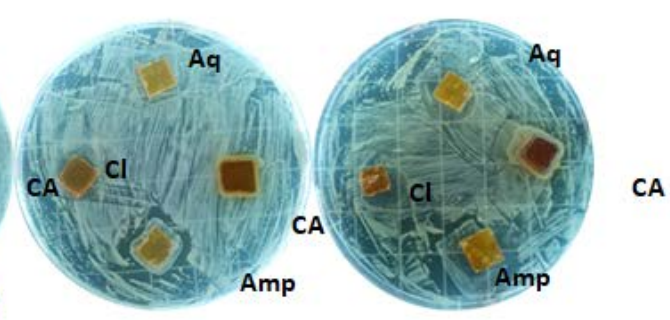

Gambar 4. Uji antibakteri dilakukan triplo pada kultur bakteri dengan menggunakan glutaraldehida $1 \%$ pada hidrogel biokomposit dengan ukuran $\pm 1 \times 1 \mathrm{~cm}$ dengan ketebalan 0,5 $\mathrm{cm}$ (a) E. coli, (b) S. aureus, dan (c) P. aeruginosa. (CA: Centella asiatica, Cl: Chloramphenicol, Amp: ampicillin, Aq: akuades).

Tabel 2

Zona Inhibisi Penggunaan Hidrogel Biokomposit Ukuran $1 \times 1 \mathrm{~cm}$ Dengan Ketebalan $0,5 \mathrm{~cm}$ Menggunakan Glutaraldehida 1\%

\begin{tabular}{cccc}
\hline & \multicolumn{3}{c}{ Diameter daerah hambat $(\mathbf{c m})$} \\
\cline { 2 - 4 } & E.coli & P. aeruginosa & S. aureus \\
\hline Centella asiatica 10\% & 0,120 & 0,233 & 0,233 \\
Chloramphenicol & 0,117 & 0,133 & 0,217 \\
Ampicillin & 0,183 & 0,000 & 0,333 \\
Akuades & 0,000 & 0,000 & 0,000 \\
\hline
\end{tabular}

*Hasil didapatkan dari rata-rata tiga kali replikasi.

Perbandingan diameter hambat koloni bakteri dilakukan. Sesuai dengan Tabel 2, terlihat bahwa biokomposit hidrogel dengan ekstrak Centella asiatica $10 \%$ memiliki efek antibakteri. Ampicillin terlihat paling efektif menghambat pertumbuhan E. coli, diikuti ekstrak Centella asiatica $10 \%$ dan chloramphenicol. Urutan yang sama juga terlihat pada S. aureus. Pada $P$. aeruginosa terlihat bahwa biokomposit hidrogel dengan ekstrak Centella asiatica $10 \%$ memiliki efek antimikroba terbaik, diikuti chloramphenicol. Biokomposit hidrogel dengan ampicillin tidak menghasilkan efek antibakteri. Hal ini didukung studi yang menunjukkan resistensi $P$. aeruginosa terhadap ampicillin (Gad et al., 2008; Sivanmaliappan \& Sevanan, 2001). Ekstrak Centella asiatica $10 \%$ terbukti memiliki aktivitas antibakteri yang mampu 
bersaing dengan antibiotik konvensional untuk membunuh bakteri penginfeksi luka. Bersama dengan biokomposit hidrogel yang telah berhasil disintesis, diharapkan formulasi keduanya mampu memberikan solusi terhadap masalah yang ada. Saat ini banyak sekali strain bakteri yang resisten terhadap antibiotik karena penggunaan antibiotik spesifik secara berlebihan. Untuk itu, diharapkan luaran penelitian ini tidak hanya mampu mempercepat penyembuhan luka, aman bagi penderita MARSI, dan meningkatkan efisiensi drug delivery, namun juga bersifat antibakteri sehingga meminimalkan risiko infeksi yang berbahaya.

Penelitian ini memiliki potensi yang sangat besar untuk dikembangkan lebih lanjut, baik dalam bentuk artikel, paten, maupun produk komersial. Diharapkan, produk ini mampu meningkatkan kualitas hidup orang dengan luka besar, serta meminimalisir angka kematian pasien oleh karena infeksi pada luka terbuka. Optimasi lanjut juga perlu dilakukan: (1) Ekstraksi Centella asiatica menggunakan pelarut yang lebih non-polar dan volatil agar senyawa antibakteri dan pemercepat penyembuhan luka dapat diekstraksi lebih banyak. Tetapi, perlu dilakukan pembuktian keamanan penggunaan pelarut tersebut dengan uji lanjut ke mencit. (2) Penambahan senyawa antifungal untuk membunuh fungi yang tumbuh pada ekstrak Centella asiatica karena diketahui adanya fungi endofit (Devi \& Wahab, 2012) yang dapat merusak dan menurunkan kualitas ekstrak saat dimasukkan ke dalam hidrogel. Perlakuan sterilisasi ekstrak dengan autoklaf (pada suhu $121^{\circ} \mathrm{C}$ selama 15 menit) juga perlu dipertimbangkan, namun perlu dipertimbangkan pula efek pemanasan terhadap penurunan aktivitas asiatic acid, madecassic acid dan asiaticosides (Kormin, 2005). (3) Pengamatan daya simpan dari campuran biokomposit hidrogel dengan ekstrak Centella asiatica. Hal ini vital untuk produksi skala besar, baik pada tahap bahan baku maupun produk jadi.

\section{SIMPULAN}

Hidrogel biokomposit ini terbukti menunjukkan aktivitas antibakteri terlihat dari zona inhibisi yang terbentuk. Hasil terbaik diperoleh dari hidrogel biokomposit berukuran $1 \times 1 \mathrm{~cm}$ dengan ketebalan $0,25 \mathrm{~cm}$. Diharapkan hidrogel biokomposit ini dapat mencegah infeksi pada luka yang disebabkan oleh bakteri Staphylococcus aureus, Pseudomonas aeruginosa, dan Escherichia coli. Untuk kedepannya perlu dilakukan optimasi hidrogel biokomposit lebih lanjut seperti ukuran dan ketebalannya dan perlu optimasi cara ekstraksi zat aktif Centella asiatica dengan menggunakan pelarut yang lebih non-polar.

\section{UCAPAN TERIMA KASIH}

Penelitian ini didanai oleh hibah Program Kreativitas Mahasiswa Penelitian Eksakta Kementerian Pendidikan dan Kebudayaan pada 2018.

\section{PUSTAKA ACUAN}

Bäckdahl, H., Helenius, G., Bodin, A., Nannmark, U., Johansson, B., Risberg, B., et al. 2006. Mechanical Properties of Bacterial Cellulosa and Interactions with Smooth Muscle Cells. Biomaterials, 27, 2141-2149.

Bayat, A. 2003. Skin Scaring. BMJ , 326 (7380): 88-92.

Bian, D., Zhang, J., Wu, X., Dou, Y., Yang, Y., Tan, Q., et al. 2013. Asiatic Acid Isolated From Centella Asiatica Inhibits TGF- $\beta 1$-induced Collagen Expression in Human Keloid Fibroblasts via PPAR- $\gamma$ Activation. Int J Biol Sci. , 9 (10), 1032-1042.

Brinkhaus, B., Lindner, M., Schuppan, D., Hahn, E. G. 2000. Chemical, pharmacological and clinical profile of the East Asian medical plant Centella asiatica. Phytomedicine, 7(5): 427-448.

Chawla, et al. 2009. Microbial Cellulose: Fermentative Production and Applications. Food Technol Biotechnol. , 47, 107-124.

Czaja, W., Krystynowicz, A., Bielecki, S., \& Brownjr, R. 2006. Microbial Cellulose the Natural Power to Heal Wounds. Biomaterials , 27, 145-151. 
Dai, T., Tanaka, M., Huang, Y.-Y., \& Hamblin, M. R. 2011. Chitosan preparations for wounds and burns: antimicrobial and wound-healing effects. National Institute of Health , 9 (7), 857-879.

Dash, R., Foston, M., \& Ragauskas, A. 2013. Improving the Mechanical and Thermal Properties of Gelatin Hydrogels Cross-linked by Cellulose Nanowhiskers Carbohydrate. Polymer, 91, 638-645.

Devi, Namerirakpam Nirjanta \& Femina Wahab. 2012. Phytochemical analysis and enzyme analysis of endophytic fungi from Centella asiatica. Asian Pasific Journal of Tropical Biomedicine, 2 (3): 1280-1284.

Farris, M. K., Petty, M., Hamilton, J., Walters, S.-A., \& Flynn, M. A. 2015. Medical AdhesiveRelated Skin Injury Medical Adhesive-Related Skin Injury Patients. J Wound Ostomy Continence Nurs. , 42 (6), 589-598.

Gad, G.F., El-Domany, R.A., Ashour, H.M. 2008. Antimicrobial susceptibility profile of Pseudomonas aeruginosa isolates in Egypt. The Journal of urology, 180(1), pp.176-181.

Gatenholm, P., \& Klemm, D. 2010. Bacterial Nanocellulose as a Renewable Material for Biomedical Applications. MRS Bull , 35, 208-213.

Guo, S., \& DiPietro, L. A. 2010. Factors Affecting Wound Healing. J Dent Res. , 89(3):219- 229.

Kormin, Saniah. 2005. The effect of heat processing on triterpene glycosides and antioxidant activity of herbal pegaga (Centella asiatica I. Urban) drink. Master thesis, Universiti Teknologi Malaysia, Malaysia.

Lalitha, V., Kiran, B., \& Raveesha, K. A. 2013. Antibacterial and Antifungal Activity of Aqueous Extract of Centella Asiatica L. Against Some Important Fungal and Bacterial Species. World Journal of Pharmacy and Pharmaceutical Sciences, 2 (6), 4744-4752.

Maramaldi, Giada, Togni, Stefano, Franceschi, Frederico, Lati, Elian. (2013). Anti-inflammaging and antiglycation activity of a novel botanical ingredient from African biodiversity (Centevita ${ }^{\mathrm{TM}}$ ). Clinical, Cosmetic and Investigational Dermatology, 7, pp. 1-9.

Mendes, P. N., Rahal, S., Pereira-Junior, O. P., Fabris, V. E., Lenharo, S. L., de LimaNeto, J. F., et al. 2009. In vivo and in vitro evaluation of anacetobacter xylinum synthesized microbial cellulose membrane intended for guided tissue repair. Acta Vet. Scand. , 51, 12.

McCaig, L. F., McDonald, L. C., Mandal, S., \& Jernigan, D. B. 2006. Staphylococcus aureus-associated Skin and Soft Tissue Infections in Ambulatory Care. Emerging Infectious Diseases , 12, 1715-1723.

Ovington, L. 2003. Bacterial Toxins and Wound Healing. Ostommy/Wound Management , 49 (Suppl 7A), 8-12.

Sen, C. K., Gordillo, G. M., Roy, S., Kirsner, R., Lambert, L., Hunt, T. K., et al. 2009.Human skin wounds: A major and snowballing threat to public. Wound Repair and Regeneration, $17(6): 763-771$.

Simon, Alice, Amaro, Maria Inês, Healy, Anne Marie, Cabral, Lucio Mendes, de Sousa, Valeria Pereira. 2016.Comparative evaluation of rivastigmine permeation from a transdermal system in the Franz cell using synthetic membranes and pig ear skin with in vivo-in vitro correlation. International Journal of Pharmaceutics, 512(1), pp. 234-241.

Sivanmaliappan, T.S., Sevanan, M., 2011. Antimicrobial susceptibility patterns of Pseudomonas aeruginosa from diabetes patients with foot ulcers. International journal of microbiology, 2011.

Somboonwong, J., Kankaisre, M., Tantisira, B., \& Tantisira, M. H. 2012. Centella asiatica in incision and burn wound models: an experimental animal study. BMC Complement Altern Med. , 12, 103.

Somchit, M. N., Sulaiman, M. R., Zuraini, A., Samsuddin, L., Somchit, N., Israf, $\quad$ D. $\quad$ A., $\quad$ et al. 2004. Antinociceptive and antiinflammatory effects of Centella asiatica. Indian J Pharmacol , 36 (6), 377-380. 
Torres, S F. G., Commeaux, S., \& Troncoso, O. P. 2012. Biocompability of Bacterial Cellulose Based Biomaterials. J. Funct. Biomater, 3, 864-878.

Treesuppharat, W., Rojanapanthu, P., Siangsanoh, C., Manuspiya, H., \& Ummartyotin, S. 2017. Synthesis and characterization of bacterial cellulose and gelatin-based. Biotechnology Reports (15), 84-91.

Ullah, H., Santos, H. A., \& Khan, T. 2016. Applications of Bacterial Cellulose In Food, Cosmetics, and Drug Delivery. Cellulose , 23 (4), 2291-2314. 